\title{
Linkage Relationships Between Mutants of Methylobacterium organophilum Impaired in their Ability to Grow on One-carbon Compounds
}

\author{
By MARY L. O'CONNOR AND R. S. HANSON \\ Department of Bacteriology, University of Wisconsin, Madison, \\ Wisconsin 53706, U.S.A.
}

(Received I4 June 1977)

Eight mutant strains of Methylobacterium organophilum which are capable of growing on succinate but not on methanol are described. Three of these contain single enzyme deficiencies while five have pleiotropic deficiencies. Some of the mutant strains are revertible to the wild-type phenotype by $N$-methyl- $N^{\prime}$-nitro- $N$-nitrosoguanidine and ethyl methanesulphonate and others are not.

Crosses between strains were performed by transformation using DNA prepared from cells which were streptomycin-resistant and either methanol ${ }^{+}$or methanol- ${ }^{-}$The frequencies of streptomycin-resistant transformants and methanol ${ }^{+}$transformants were $^{-}$ determined independently. Four of the methanol ${ }^{-}$mutant strains appeared to contain mutations which are linked to each other (group I) while the other four (group 2) appeared to contain mutations not linked to the first four. In reciprocal crosses with the group 2 markers, two appeared to be linked to each other, while the other two were not linked to any mutant tested.

The data presented were used to construct a model for the organization of these genes in which the CO-binding cytochrome $c$ is not linked to the five genes for $\mathrm{C}_{1}$-specific enzymes. In this model, the expression of $\operatorname{six} \mathrm{C}_{1}$-specific functions is controlled by a common regulatory agent.

\section{INTRODUCTION}

Several enzymes responsible for carbon assimilation during growth on $\mathrm{C}_{1}$ compounds are coordinately expressed in the facultative methanol-utilizing bacterium, Pseudomonas Am1, and the facultative methane-utilizing bacterium, Methylobacterium organophilum (Large \& Quayle, 1963; Dunstan, Anthony \& Drabble, 1972; O’Connor \& Hanson, 1977). In $M$. organophilum, the ability to oxidize methane and the synthesis of intracytoplasmic membranes occur only in methane-grown cells (Patt et al., 1974, 1977). In the past, coordinate expression of enzymes in response to the substrate they act upon has been an indication of control by a regulon or operon (Jacob \& Monod, I96 I $a, b$; Buttin, I962; Englesberg et al., 1965; Power, 1967; Ames, Garry \& Herzenberg, 1960; Lester \& Yanofsky, $1961)$.

Several mutants have been isolated in $M$. organophilum which are pleiotropically negative for several enzymes involved in the utilization of $C_{1}$ compounds ( $O$ 'Connor \& Hanson, 1977). Pleiotropy in other bacteria has been explained by mutations in an operon resulting from deletions, polar nonsense or frameshift mutations, or mutations in regulatory genes (Goldberger \& Berberich, I966; Yanofsky \& Ito, I966; Cohn \& Monod, I953).

The existence of an operon for the genes specifying enzymes involved in the utilization of 
$\mathrm{C}_{1}$ compounds in $M$. organophilum can be verified by genetic mapping. This paper describes the determination of genetic linkage relationships between $\mathrm{C}_{1}$ mutants of $M$. organophilum, using genetic transformation as a mapping tool.

\section{METHODS}

Organism. Methylobacterium organophilum (ATCC27886, Patt, Cole \& Hanson, 1976) was used in all experiments.

Media and growth conditions. The modified nitrate mineral salts medium (NMS) previously described (Patt et al., 1976) was used for all studies. Succinate and yeast extract were dissolved in distilled water, sterilized separately and added directly to the growth medium at concentrations of $0.1 \%(\mathrm{w} / \mathrm{v})$ and $0.05 \%$ $(\mathrm{w} / \mathrm{v})$ respectively. Methanol $(96 \%, \mathrm{v} / \mathrm{v})$ and streptomycin were filter-sterilized and added separately to the growth medium at concentrations of $0.5 \%(\mathrm{v} / \mathrm{v})$ and $0.005 \%(\mathrm{w} / \mathrm{v})$, respectively. All cultures were incubated at $30{ }^{\circ} \mathrm{C}$. Liquid cultures were incubated on rotary shakers.

Preparation of extracts. Extracts used for enzyme assays were prepared as described previously ( $O^{\prime}$ Connor

\& Hanson, 1975). Protein was estimated by the method of Lowry et al. (195I).

Enzyme activities. Enzymes were assayed as described previously (O'Connor \& Hanson, 1977).

Cytochrome detection. Cytochrome was detected on polyacrylamide gels using the gel buffer system and the staining method described by Clarke (1964). Samples containing $200 \pm 20 \mu \mathrm{g}$ protein were added to each gel.

Mutant isolation. Mutants unable to grow on $\mathrm{C}_{1}$ compounds were isolated using the ultraviolet light procedure described previously (O'Connor, Wopat \& Hanson, 1977).

Reversion tests. Revertants were obtained using $N$-methyl- $N^{\prime}$-nitro- $N$-nitrosoguanidine (NTG) and ethyl methanesulphonate (EMS) as described previously (O'Connor \& Hanson, 1977).

DNA isolation. DNA was isolated as described previously (O'Connor et al., 1977).

Transformation. Transformation experiments were carried out using the method described previously (O'Connor et al., 1977). DNA ( $50 \mu \mathrm{g} \mathrm{ml}^{-1}$ ) was incubated with the bacteria during growth. Cultures containing $0.1 \times$ SSC (SSC: $0.15 \mathrm{M}$-sodium chloride/0.0 $5 \mathrm{M}$-sodium citrate, $\mathrm{pH} 7.3$ ) in place of DNA were included as controls for reversion with each experiment. The total number of recipient bacteria',was determined by total viable counts on NMS medium plus yeast extract and succinate or methanol as the carbon and energy sources. Streptomycin-resistant $\left(\mathrm{Sm}^{\mathrm{R}}\right)$ transformants were detected using an overlay technique. Plates of NMS media with the appropriate carbon and energy source were spread with potential transformants and incubated overnight at $30{ }^{\circ} \mathrm{C} ; 2.5 \mathrm{ml}$ of $0.6 \%$ (w/v) agar containing $100 \mu \mathrm{g}$ streptomycin $\mathrm{ml}^{-1}$ was then layered on top of the bottom agar. The streptomycin-resistant clones were scored after 7 days incubation at $30^{\circ} \mathrm{C}$.

Strain construction. Streptomycin-resistant mutants of isolates $8 \mathrm{z}$ and $4 \mathrm{M}$ were prepared by transformation, using DNA from a streptomycin-resistant strain (O'Connor et al., 1977).

Antiserum. Antiserum was prepared in rabbits against purified methanol dehydrogenase (H. Woif \& R.S. Hanson, unpublished results). Two injections of $\mathrm{I} \mathrm{mg}$ each of purified methanol dehydrogenase (from $M$. organophilum) incorporated in Freund's complete adjuvant were given intramuscularly to random-bred New Zealand rabbits at I week intervals. Two weeks later, three intravenous injections of $0.2 \mathrm{mg}$ soluble antigen each were given at 2 day intervals. The rabbits were bled by marginal ear puncture $\mathrm{r}$ week later and at intervals during the following weeks. From the blood obtained, serum was prepared, pooled, titred and stored at $-20^{\circ} \mathrm{C}$. When necessary, booster doses of I mg of enzyme in Freund's complete adjuvant were given intramuscularly to increase the titre.

Cross-reactivity was determined by the Ouchterlony double diffusion technique (Ouchterlony, 1949). Reactions were carried out at $20^{\circ} \mathrm{C}$ and interpreted after $24 \mathrm{~h}$ incubation.

\section{RESULTS}

\section{Mutants}

The mutants used in this study are described in Table I. All were unable to grow on methanol, but were able to grow on NMS medium with succinate and yeast extract as the carbon and energy sources. All mutants were routinely grown on media containing succinate plus yeast extract. For enzyme studies, all strains were grown on media containing succinate plus yeast extract plus methanol. The enzyme activities in mutants $8 \mathrm{Z}, 17 \mathrm{M}, 4 \mathrm{M}, 7 \mathrm{~A}, 17 \mathrm{~A}$ and 8A were published previously (O'Connor \& Hanson, I977).

The properties of methanol-dependent cytochromes in Pseudomonas AM1 have been 


\section{Table I. Phenotypes of mutants and wild-type $M$. organophilum}

Cultures were grown on media containing $0.1 \%$ succinate, $0.5 \%$ methanol and $0.05 \%$ yeast extract. Enzyme activities are expressed as $\mu \mathrm{mol} \mathrm{min}^{-1}$ (mg protein) ${ }^{-1}$ and are the average of two or more experiments. Values agreed within $\pm 20 \%$.

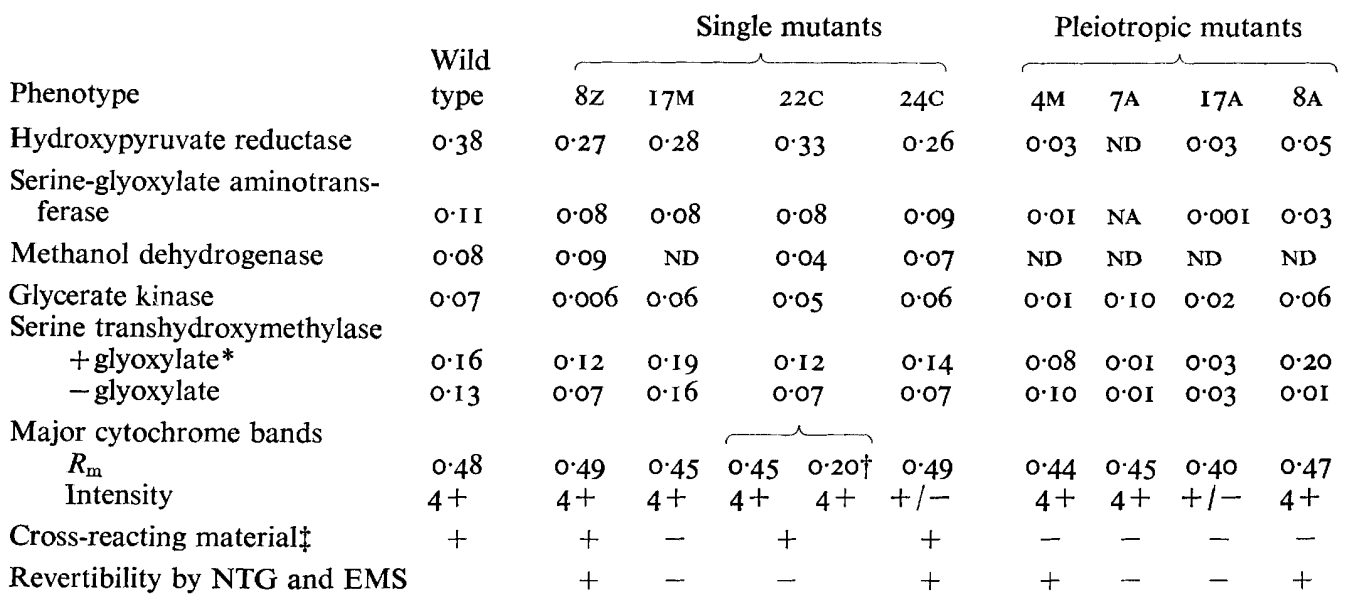

ND, Not detected; NA, not assayed.

* Assayed in the presence of 5 mM-glyoxylate which stimulates the activity of the isoenzyme predominant in cells grown on methanol (O'Connor \& Hanson, 1975).

+ The cytochrome band with an $R_{\mathrm{m}}$ of 0.20 was not detected in other strains.

$\$$ Antisera prepared against purified methanol dehydrogenase.

described by Anthony (1975) and Widdowson \& Anthony (1975). A mutant in the facultative methanol-oxidizing bacterium, Pseudomonas AM1, which lacks cytochrome $c$ is unable to grow on methanol (Anthony, 1975). Tonge and co-workers (1975) have discussed a possible role for cytochrome $c$ in Methylosinus trichosporium. The cytochrome $c$ from $M$. organophilum resembles that from $P$ seudomonas AM1 in spectral properties (oxidized minus reduced and $\mathrm{CO}$ minus reduced difference spectra) as well as having a similar molecular weight (H. Wolf \& R. S. Hanson, unpublished results).

A cytochrome which appears identical to cytochrome $c$ from Pseudomonas Am1 was readily detected using the gel system developed by Clarke (1964) in which haem proteins were detected by staining polyacrylamide gels with benzidine reagent. This cytochrome occurred as the only dark-staining band in extracts of wild-type cells grown on methanol or methanol plus succinate and had a relative mobility of 0.48 . Other haem proteins occurred as very light-staining bands on these gels. A purified preparation of cytochrome $c$ from $M$. organophilum had a relative mobility of 0.48 and was found only in cells grown in the presence of methanol (J. Bishop, H. Wolf, M. O'Connor \& R. S. Hanson, unpublished results). The cytochrome detection system was not quantified, but identical gels containing differing amounts of protein showed corresponding differences in the intensity of the cytochrome band.

Mutant strain $8 \mathrm{z}$ had low levels of glycerate kinase (EC 2.7.I.3I), mutant I7M lacked methanol dehydrogenase (EC'I.I.99.8), and mutant 24C had low levels of cytochrome $c$. Mutant $22 \mathrm{C}$ had a second intense cytochrome band not seen in the wild type, and had lower levels of methanol dehydrogenase than the wild-type strain. The other four mutants lacked methanol dehydrogenase activity and had low levels of two or more other enzymes. Mutants $8 \mathrm{z}, 24 \mathrm{C}, 4 \mathrm{M}$ and $8 \mathrm{~A}$ were revertible to the methanol ${ }^{+}$phenotype by NTG and EMS, while the other four isolates were not. Enzyme levels were not tested in these revertants. All mutants which lacked methanol dehydrogenase activity, also lacked cross-reacting material to antiserum prepared against purified methanol dehydrogenase. 
Table 2. Transformation frequencies for crosses involving methanol- recipient cells and DNA from streptomycin-resistant $\left(\mathrm{Sm}^{\mathrm{R}}\right)$ cells which were either methanol ${ }^{+}$or methanol- ${ }^{-}$strain $\left.8 \mathrm{z}\right)$

Frequencies are expressed as the ratio of the number of methanol ${ }^{+}$or streptomycin-resistant recombinants to the total number of recipient cells. All controls containing no DNA had frequencies of less than $10^{-7}$.

\begin{tabular}{|c|c|c|c|c|}
\hline \multirow[b]{2}{*}{ Recipient } & \multicolumn{2}{|c|}{ Methanol ${ }^{+} /$total } & \multicolumn{2}{|c|}{$\mathrm{Sm}^{\mathrm{R}} /$ total } \\
\hline & $8 \mathrm{z} \mathrm{Sm}{ }^{\mathrm{K}}$ DNA & $\mathrm{Sm}^{\mathrm{R}} \mathrm{DNA}$ & $8 z \mathrm{Sm}^{\mathrm{R}}$ DNA & $\mathrm{Sm}^{\mathrm{R}} \mathrm{DNA}$ \\
\hline $4 \mathrm{M}$ & $\begin{array}{l}<10^{-7} \\
<10^{-7}\end{array}$ & $\begin{array}{l}1.1 \times 10^{-6} \\
6.5 \times 10^{-6}\end{array}$ & $\begin{array}{l}4.0 \times 10^{-5} \\
6.0 \times 10^{-6}\end{array}$ & $\begin{array}{l}3.5 \times 10^{-6} \\
5.2 \times 10^{-5}\end{array}$ \\
\hline $7 \mathrm{~A}$ & $\begin{array}{l}<10^{-7} \\
<10^{-7}\end{array}$ & $\begin{array}{l}6.0 \times 10^{-5} \\
7.4 \times 10^{-5}\end{array}$ & $\begin{array}{l}1.2 \times 10^{-5} \\
4.6 \times 10^{-5}\end{array}$ & $\begin{array}{l}3.0 \times 10^{-5} \\
3.1 \times 10^{-5}\end{array}$ \\
\hline $17 \mathrm{M}$ & $\begin{array}{l}<10^{-7} \\
<10^{-7}\end{array}$ & $\begin{array}{l}3.3 \times 10^{-5} \\
1.0 \times 10^{-5}\end{array}$ & $\begin{array}{l}1.0 \times 10^{-6} \\
6.0 \times 10^{-6}\end{array}$ & $\begin{array}{l}7.7 \times 10^{-6} \\
1 \cdot 3 \times 10^{-5}\end{array}$ \\
\hline $8 z$ & $<\mathrm{IO}^{-7}$ & $1.0 \times 10^{-6}$ & $\mathrm{I} \cdot 2 \times 1 \mathrm{IO}^{-5}$ & $2.5 \times 10^{-5}$ \\
\hline $24 \mathrm{C}$ & $\begin{array}{l}7.5 \times 10^{-6} \\
2.8 \times 10^{-5}\end{array}$ & $\begin{array}{l}1.0 \times 10^{-5} \\
6.6 \times 10^{-6}\end{array}$ & $\begin{array}{l}4.0 \times 10^{-6} \\
5.0 \times 10^{-5}\end{array}$ & $\begin{array}{l}6.2 \times 10^{-6} \\
3.0 \times 10^{-5}\end{array}$ \\
\hline $22 \mathrm{C}$ & $\begin{array}{l}6.0 \times 10^{-6} \\
1.0 \times 10^{-6}\end{array}$ & $\begin{array}{l}2.0 \times 10^{-5} \\
1 \cdot 4 \times 10^{-5}\end{array}$ & $\begin{array}{l}3.2 \times 10^{-6} \\
1 \cdot 0 \times 10^{-5}\end{array}$ & $\begin{array}{l}1.4 \times 10^{-5} \\
6.0 \times 10^{-5}\end{array}$ \\
\hline I $7 \mathrm{~A}$ & $\begin{array}{l}7.5 \times 10^{-5} \\
1.0 \times 10^{-6}\end{array}$ & $\begin{array}{l}7.5 \times 10^{-5} \\
7.5 \times 10^{-6}\end{array}$ & $\begin{array}{l}8.0 \times 10^{-5} \\
2.0 \times 10^{-5}\end{array}$ & $\begin{array}{l}5.0 \times 10^{-6} \\
5.0 \times 10^{-5}\end{array}$ \\
\hline $8 \mathrm{~A}$ & $\begin{array}{l}2.5 \times 10^{-6} \\
8.5 \times 10^{-6}\end{array}$ & $\begin{array}{l}2.0 \times 10^{-5} \\
8.3 \times 10^{-6}\end{array}$ & $\begin{array}{l}5.6 \times 10^{-5} \\
1 \cdot 2 \times 10^{-6}\end{array}$ & $\begin{array}{l}1.7 \times 10^{-6} \\
6.7 \times 10^{-6}\end{array}$ \\
\hline
\end{tabular}

Table 3. Transformation frequencies for crosses involving methanol- recipient cells and DNA

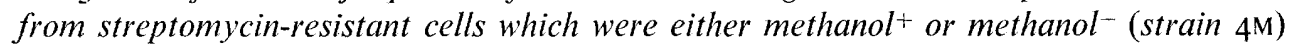

Frequencies are expressed as the ratio of the number of methanol ${ }^{+}$or streptomycin-resistant recombinants to the total number of recipient cells. All controls containing no DNA had frequencies of less than $10^{-7}$.

\begin{tabular}{|c|c|c|c|c|}
\hline \multirow[b]{2}{*}{ Recipient } & \multicolumn{2}{|c|}{ Methanol /total } & \multicolumn{2}{|c|}{$\mathrm{Sm}^{\mathrm{R}} /$ total } \\
\hline & $4 \mathrm{MSm}{ }^{\mathrm{R}} \mathrm{DNA}$ & $\mathrm{Sm}^{\mathrm{K}} \mathrm{DNA}$ & $4 \mathrm{M} \mathrm{Sm}^{\mathrm{R}}$ DNA & $\mathrm{Sm}^{\mathrm{R}} \mathrm{DNA}$ \\
\hline $4 M$ & $<10^{-7}$ & $4.0 \times 10^{-6}$ & $7 \cdot 2 \times 10^{-6}$ & $2.8 \times 10^{-5}$ \\
\hline $7 \mathrm{~A}$ & $<10^{-7}$ & $1.6 \times 10^{-5}$ & $1 \cdot 2 \times 10^{-5}$ & $7 \cdot 5 \times 10^{-6}$ \\
\hline $17 \mathrm{M}$ & $<10^{-7}$ & $1 \cdot 3 \times 10^{-5}$ & $3.0 \times 10^{-5}$ & $2 \cdot 2 \times 10^{-5}$ \\
\hline $8 \mathrm{z}$ & $<\mathrm{IO}^{-7}$ & $4.4 \times 10^{-6}$ & $1.5 \times 10^{-5}$ & $4.0 \times 10^{-5}$ \\
\hline $24 \mathrm{C}$ & $1 \cdot 2 \times 10^{-6}$ & $1.7 \times 10^{-5}$ & $3.7 \times 10^{-6}$ & $5.0 \times 10^{-6}$ \\
\hline $22 \mathrm{C}$ & $1.9 \times 10^{-5}$ & $3.0 \times 10^{-5}$ & $2 \cdot 3 \times 10^{-5}$ & $1.4 \times 10^{-5}$ \\
\hline $17 \mathrm{~A}$ & $1.0 \times 10^{-6}$ & $6.3 \times 10^{-5}$ & $2.3 \times 10^{-5}$ & $6.7 \times 10^{-6}$ \\
\hline $8 \mathrm{~A}$ & $3.0 \times 10^{-5}$ & $4.0 \times 10^{-6}$ & $7 \cdot 7 \times 10^{-6}$ & $2.0 \times 10^{-5}$ \\
\hline
\end{tabular}

Strain construction

Attempts were made to transform methanol- markers from $17 \mathrm{M}$ and $8 \mathrm{z}$ into the highly transformable glutamate auxotroph described previously (O'Connor et al., 1977). Transformation frequencies of $10^{-3}$ were expected. However, although over 20000 colonies were examined, no methanol- ${ }^{-}$glutamate ${ }^{-}$mutants were isolated. Streptomycin-resistant methanol- mutants were constructed by adding DNA from a streptomycin-resistant strain to methanol- recipient strains $8 \mathrm{z}$ and $4 \mathrm{M}$. Transformation frequencies were approximately $10^{-5}$.

\section{Linkage relationships}

DNA preparations from the streptomycin-resistant mutants of strains $8 \mathrm{Z}$ and $4 \mathrm{M}$ were used in transformation studies to determine linkage relationships with the eight methanolmutants. Each mutant was incubated with DNA from streptomycin-resistant methanolcells, with DNA from streptomycin-resistant methanol ${ }^{+}$cells, or without DNA. The number of methanol ${ }^{+}$transformants and the number of streptomycin-resistant transformants were determined independently in each cross. 
Table 4. Transformation frequencies for crosses involving methanol- recipient cells and DNA from methanol ${ }^{+}$or methanol- ${ }^{-}$cells

Frequencies are expressed as the ratio of the number of methanol ${ }^{+}$recombinants to the total number of recipient cells. All controls containing no DNA had frequencies of less than $10^{-7}$.

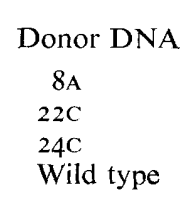

\begin{tabular}{ccc} 
& Recipient \\
\hline $8 \mathrm{~A}$ & $17 \mathrm{~A}$ & $24 \mathrm{C}$ \\
$\mathrm{ND}$ & $6.7 \times 10^{-5}$ & $2.3 \times 10^{-5}$ \\
$8.0 \times 10^{-6}$ & $2.5 \times 10^{-5}$ & $<10^{-7}$ \\
$7.5 \times 10^{-5}$ & $8.0 \times 10^{-5}$ & $\mathrm{ND}$ \\
$2.9 \times 10^{-5}$ & $1.0 \times 10^{-5}$ & $5.0 \times 10^{-6}$
\end{tabular}

ND, Not done.

The results of the crosses are presented in Tables 2 and 3. In each cross, streptomycinresistant and methanol ${ }^{+}$transformants were obtained when DNA from a streptomycinresistant methanol ${ }^{+}$strain was used. However, when DNA from streptomycin-resistant mutants of methanol- strains $8 \mathrm{z}$ or $4 \mathrm{M}$ was used, streptomycin-resistant transformants were obtained but no methanol ${ }^{+}$transformants were found when mutant strains $4 \mathrm{M}, 7 \mathrm{~A}, 17 \mathrm{M}$ or $8 \mathrm{z}$ were used as recipients. The other four mutants $(22 \mathrm{C}, 24 \mathrm{C}, 8 \mathrm{~A}$ and $17 \mathrm{~A})$ yielded methanol ${ }^{\text {t }}$ recombinants with DNA from both methanol ${ }^{-}$and methanol ${ }^{+}$strains.

Reciprocal crosses between mutants $22 \mathrm{C}, 24 \mathrm{C}, 8 \mathrm{~A}$ and $\mathrm{I} 7 \mathrm{~A}$ produced methanol ${ }^{+}$ recombinants in all cases except that of $24 \mathrm{C}$ crossed with $22 \mathrm{C}$ (Table 4 ).

\section{Reversion of a streptomycin-resistant mutant of isolate $4 \mathrm{M}$}

A streptomycin-resistant mutant of isolate $4 \mathrm{M}$ was reverted to a streptomycin-resistant methanol ${ }^{+}$phenotype using EMS. Activities of glycerate kinase, serine transhydroxymethylase, serine-glyoxylate aminotransferase, hydroxypyruvate reductase and methanol dehydrogenase were at partially constitutive levels in cells of this revertant grown on succinate. These levels were 20 to $40 \%$ lower than those in wild-type cells grown on methanol plus succinate. The level of cytochrome $c$ was similar to that found in wild-type cells grown on succinate.

\section{DISCUSSION}

Evidence is presented which suggests genetic linkage for some $\mathrm{C}_{1}$-specific functions in $M$. organophilum. Non-detectable transformation frequencies in crosses between methanolmutants suggest there is genetic linkage between the two markers tested. The transfer of a streptomycin-resistance marker indicated that the cells in each cross were competent, while the transfer of methanol ${ }^{+}$markers into methanol- mutants showed that each mutant was capable of being transformed to the methanol ${ }^{+}$phenotype.

Isolates $8 \mathrm{Z}$ and $4 \mathrm{M}$ were shown to be linked in reciprocal crosses, and each was found to be linked to $17 \mathrm{M}$ and $7 \mathrm{~A}$. Crosses between donor strains $8 \mathrm{z}$ and $4 \mathrm{M}$ and recipient strains $8 \mathrm{~A}$, $17 \mathrm{~A}, 22 \mathrm{C}$ and $24 \mathrm{C}$ resulted in methanol ${ }^{+}$transformants at frequencies approximately equal to those obtained with wild-type DNA. In addition, reciprocal crosses between these four markers indicate that $22 \mathrm{C}$ and $24 \mathrm{C}$ are linked only to each other, and $8 \mathrm{~A}$ and $17 \mathrm{~A}$ are not linked to any of the markers tested.

The transformation frequencies obtained varied over a 10-fold range, and the data were not adequate for fine-structure mapping. However, the linkage relationships outlined above, combined with the characteristics of the mutants, allow the formulation of a plausible model which is consistent with all the data (Fig. I).

Mutant $24 \mathrm{C}$ appears to be a point mutation in a gene required for production of cytochrome $c$. Mutant $22 \mathrm{C}$ appears to produce an altered cytochrome. Isolates $22 \mathrm{C}$ and $24 \mathrm{C}$ are 


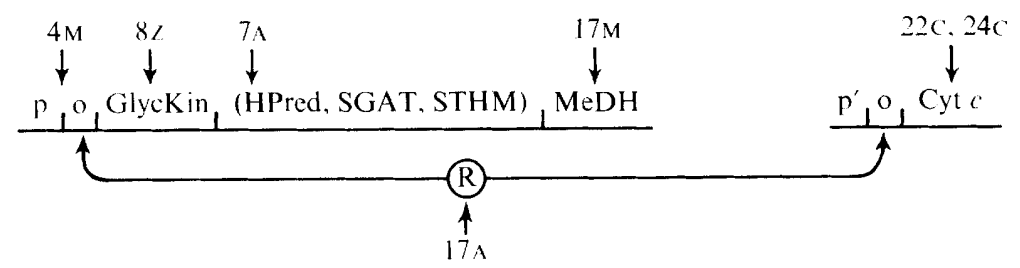

Fig. I. Model for the arrangement of genes coding for $\mathrm{C}_{1}$-specific functions in Methylobacterium organophilum.

The mutant phenotypes were: $\mathbf{I} 7 \mathrm{M}$, non-revertible $\mathrm{MeDH}^{-} ; 8 \mathrm{z}$, revertible GlycKin ${ }^{\text {low }}$; $4 \mathrm{M}$, revertible HPred ${ }^{10 w}$ SGAT $^{10 w}$ GlycKin $^{\text {low }}$ STHM $^{-}$MeDH $^{-}$; I 7A, non-revertible HPred ${ }^{10}$ w SGAT $^{\text {tow }}$ GlycKin'ow STHM $^{-}$MeDH $^{-}$Cyt $^{10 w}$; 7A, non-revertible HPred- ${ }^{-}$SGAT $^{-}$STHM $^{-}$MeDH $^{-}$; 24C, revertible Cyt ${ }^{10 w} ; 22 \mathrm{C}$, non-revertible extra Cyt band; 8A, revertible HPred ${ }^{10 \mathrm{w}}$ SGAT $^{\text {low }}$ $\mathrm{MeDH}^{-}$.

GlycKin, Glycerate kinase; HPred, hydroxypyruvate reductase; SGAT, serine-glyoxylate aminotransferase; Cyt, cytochrome $c$; STHM, serine transhydroxymethylase (glyoxylate activating); $\mathrm{MeDH}$, methanol dehydrogenase; low, detectable but less than $25 \%$ of wild-type activity; - not detectable; $\mathrm{p}, \mathrm{p}^{\prime}$, promoter; $\mathrm{o}$, operator; $\mathrm{R}$, regulatory agent.

unlinked to all other mutants tested, but are linked to each other. Cytochrome $c$ is induced by methanol, and it is assumed that a common regulatory agent $(R)$ is involved in controlling both sets of genes.

Mutant $17 \mathrm{~A}$ is a non-revertible mutant with lowered levels of all $\mathrm{C}_{1}$-specific enzymes tested and cytochrome $c$. It is not linked to any of the other mutants. There is not sufficient data to determine whether the proposed regulatory agent is a protein or a low molecular weight molecule, or whether it acts in a positive or negative manner.

Mutants $4 \mathrm{M}, 8 \mathrm{z}, 7 \mathrm{~A}$ and $17 \mathrm{M}$ all contain mutations which are linked to each other. Therefore, in the model they are placed adjacent to one another. Isolate $4 \mathrm{M}$ contains lowered levels of the five $\mathrm{C}_{1}$-specific enzymes, but not cytochrome $c$, and it is revertible. One revertant of isolate $4 \mathrm{M}$ was partially constitutive for the five $\mathrm{C}_{\mathbf{1}}$-specific enzymes. This supports the possibility that the lesion in $4 \mathrm{M}$ may involve a regulatory component, possibly an operator or promoter. This information does not rule out either positive or negative control in this system, since partially constitutive revertants of regulatory mutants have been described in both positive (Gielow, Largen \& Englesberg, 197I) and negative (Arditti, Scaife \& Beckwith, I968) control systems. Mutant $8 \mathrm{z}$ has a revertible mutation in glycerate kinase. Mutant 7 A contains a non-revertible mutation which results in no detectable activity of four of the $\mathrm{C}_{1}$-specific enzymes. It should be noted that the assay for serine-glyoxylate aminotransferase (EC 2.6.I.45) is coupled to hydroxypyruvate reductase (EC I.I.I.29). Therefore, when there is no detectable hydroxypyruvate reductase activity, serine-glyoxylate aminotransferase cannot be assayed. At present, there is no source of hydroxypyruvate reductase free of serine-glyoxylate aminotransferase activity available to us that could be used for this assay. Isolate $7 \mathrm{~A}$ is assumed to be a deletion, and is placed distal to $8 \mathrm{z}$, since it has wild-type levels of glycerate kinase. Mutation $17 \mathrm{M}$ is positioned at the end of the operon because it is a non-revertible mutation which affects only methanol dehydrogenase.

The deficiencies in hydroxypyruvate reductase, serine transhydroxymethylase (EC 2.I.2.I) and serine-glyoxylate aminotransferase in mutant $7 \mathrm{~A}$ might result from defects in structural genes or defects in one or more genes regulating the synthesis of these three enzymes.

Isolate $8 \mathrm{~A}$ also appears to be a regulatory mutant. It is revertible and unlinked to the other mutants and affects the synthesis of at least three $\mathrm{C}_{1}$-specific enzymes. Since there was no detectable cross-reacting material for methanol dehydrogenase in this mutant, the mutation probably does not affect a component which interacts with the intact enzyme molecules. The low level of serine transhydroxymethylase in the absence of glyoxylate for isolate 8A might suggest that the cellular pool of glyoxylate is very low in this mutant. The level of 
serine transhydroxymethylase in the presence of glyoxylate is similar to that in the wild type.

The inducibility of all other $\mathrm{C}_{1}$-specific enzymes in a mutant lacking methanol dehydrogenase (mutant $17 \mathrm{M}$ ) suggests that the inducer in this system is either methanol, or some compound derived from methanol via an unknown pathway unaffected by the absence of methanol dehydrogenase.

We are grateful to Holly Wolf for her assistance in the antiserum studies and to Dr Martha Howe for her helpful comments concerning the mapping studies. M. L. O'Connor was supported by a predoctoral fellowship from the American Association of University Women. This research was also supported by the College of Agricultural and Life Sciences, University of Wisconsin, Madison, and a grant from the National Science Foundation (BMS 75-14912).

\section{REFERENCES}

Ames, B. N., Garry, B. \& HerzenberG, L. A. (1960). The genetic control of the enzymes of histidine biosynthesis in Salmonella typhimurium. Journal of General Microbiology 22, 369-375.

ANTHONY, C. (1975). The microbial metabolism of $\mathrm{C}_{1}$ compounds. The cytochromes of Pseudomonas AM1. Biochemical Journal 146, 289-298.

Arditti, R. R., Scalfe, J. \& Beckwith, J. R. (I968). The nature of mutants in the LAC promoter region. Journal of Molecular Biology $\mathbf{3}^{8}$, $42 I-426$.

Buttin, G. (I962). Sur la structure de l'operon galactose chez $E$. coli K-I2. Comptes rendus hebdomadaire des Séances de l'Académie des sciences 255, I233-I $24 \mathrm{I}$.

Clarke, J.T. (1964). Simplified 'disc' (polyacrylamide gel) electrophoresis. Annals of the New York Academy of Sciences 121, 428-444.

Cohn, M. \& Monod, J. (1953). Specific inhibition and induction of enzyme synthesis. Symposia of the Society for General Microbiology 3, 132-140.

Dunstan, P. M., Anthony, C. \& Drabble, W. T. (1972). Microbial metabolism of $C_{1}$ and $C_{2}$ compounds. The role of glyoxylate, glycollate and acetate in the growth of Pseudomonas AM1 on ethanol and on $\mathrm{C}_{1}$ compounds. Biochemical Journal 128, I07-115.

Englesberg, E., Irr, J., Power, J. \& Lee, N. (I965). Positive control of enzyme synthesis by gene $C$ in the $\mathbf{L}$-arabinose system. Journal of Bacteriology 90, 946-955.

Gielow, L., Largen, M. \& Englesberg, E. (I97I). Initiator constitutive mutants of the L-arabinose operon (OI-BAD) of Escherichia coli $\mathrm{B} / \mathrm{r}$. Genetics 69, 289-302.

Goldberger, R. R. \& Berberich, M. A. (ig66). Studies on the mechanism of derepression of the histidine operon in S. typhimurium. Federation Proceedings 25, 337-338.

JACOB, F. \& MONOD, J. (I96I $a$ ). Genetic regulatory mechanisms in the synthesis of proteins. Journal of Molecular Biology 3, 31 8-325.

JACOB, F. \& MoNOD, J. (196I $b$ ). On the regulation of gene activity. Cold Spring Harbor Symposia on Quantitative Biology 26, 193-210.

Large, P. J. \& Quayle, J. R. (I963). Microbial growth on $\mathrm{C}_{1}$ compounds. 5. Enzyme activities in extracts of Pseudomonas AM1. Biochemical Journal 87, 386-396.

LESTER, G. \& YANOFSKY, C. (I96I). Influence of 3-methylanthranilic acids on the formation of tryptophan synthetase in Escherichia coli. Journal of Bacteriology 8I, 8I-95.

Lowry, O. H., Rosebrough, N. J., Farr, A. L. \& RANDALl, R. J. (I95I). Protein measurement with the Folin phenol reagent. Journal of Biological Chemistry r93, 265-275.

O'Connor, M. L. \& Hanson, R. S. (1975). Serine transhydroxymethylase isoenzymes from a facultative methylotroph. Journal of Bacteriology 124, 985-996.

O'Connor, M. L. \& Hanson, R. S. (1977). Enzyme regulation in Methylobacterium organophilum. Journal of General Microbiology ror, 327-332.

O'Connor, M. L., Wopat, A. E. \& Hanson, R. S. (1977). Genetic transformation in Methylobacterium organophilum. Journal of General Microbiology 98, 265-272.

Ouchterlony, O. (1949). Antigen-antibody reactions in gels. Acta pathologica et microbiologica scandinavica 26, 507-515.

Patt, T. E., Cole, G. C., Bland, J. \& Hanson, R.S. (1974). Isolation and characterization of bacteria that grow on methane and organic compounds as sole sources of carbon and energy. Journal of Bacteriology 120, 955-964.

Patt, T. E., Cole, G. C. \& Hanson, R. S. (1976). Methylobacterium, a new genus of facultatively methylotrophic bacteria. International Journal of Systematic Bacteriology 26, 226-229.

Patt, T. E., O'Connor, M. L., Cole, G. C., Day, R. \& Hanson, R. S. (I977). Characterization of a facultative methylotrophic bacterium. In Microbial Production and Utilization of Gases, pp. 317-327. Edited by H. G. Schlegel, G. Gottschalk and N. Pfennig. Göttingen: Akademie der Wissenschaften zu Göttingen.

POWER, J. (1967). The L-rhamnose genetic system in Escherichia coli K-12. Genetics 55, 557-568.

Tonge, G. M., Harrison, D. E. F., Knowles, C. J. \& Higgins, I. J. (1975). Properties and partial purification of the methane-mono-oxygenase enzyme system from Methylosinus trichosporium. FEBS Letters 58, 293-299.

Widdowson, D. \& ANTHONY, C. (1975). The microbial metabolism of $C_{1}$ compounds. The electron transport chain of Pseudomonas AM1. Biochemical Journal 152, 349-356.

YANOFSKY, C. \& ITO, J. (I966). Nonsense codons and polarity on the trytophan operon. Journal of Molecular Biology 21, 313-323. 